\title{
How Children's Creativity During the Covid-19 Pandemic?
}

\author{
Eklys Cheseda Makaria $^{1^{*}}$ and Nina Permata Sari ${ }^{2}$
}

\author{
${ }^{12}$ Lambung Mangkurat University \\ *Corresponding author. Email: eklys.makaria@ulm.ac.id
}

\begin{abstract}
This study was conducted to describe the creativity of early childhood and how to develop children's creativity during the Covid-19 pandemic. The method used is descriptive qualitative literature. Obtaining data was compiled, analyzed, and concluded. The results show that the creativity of early childhood during the Covid-19 period can be developed through online learning, using social modeling and traditional games. This method requires synergy from parents and teachers to optimize every aspect of children's development and creativity when learning from home.
\end{abstract}

Keywords: creativity, early childhood, the covid-19 pandemic

\section{INTRODUCTION}

In early 2020, regions around the world were in an uproar because of the covid-19 virus disease outbreak. All parts of life seem paralyzed to break the chain of disease outbreaks. The world of education is no exception, schools ranging from early childhood education to tertiary institutions are urged not to do face-to-face learning. To overcome this problem, the government, especially Indonesia, initiated a home learning program, which is also known as BDR (Belajar Dari Rumah/Learning From Home). With this BDR program, the Indonesian government issued an Emergency Curriculum in the Ministry of Education and Culture Decree Number 719 / P / 2020 concerning Guidelines for Implementing Curriculum in Education Units in Special Conditions [1]. These guidelines stipulate that learning policies ranging from Early Childhood Education, Elementary and Secondary Education in special conditions may implement curricula according to the needs of students regulated by schools or educational institutions.

The learning process of early childhood is usually guided and directed by educators or teachers or parents of children. When learning at home, the child's supervisor is the parent or adult who is at home with the child. Instructional guidance and instruction can also be

carried out by educators or teachers, either through online (online) in the form of virtual meetings via Google Meet, Zoom, WeBeX, Video Call Group, learning applications such as Classroom, Youtube, teacher rooms, and others. Apart from being online, learning is also carried out offline (outside the network) such as through WhatsApp, telephone, home visits, or taking assignments to school once a week or once a month. Therefore, parents are the ones who play a more active role in guiding the learning process of early childhood at home, so it strives for teachers to choose media and learning resources that are also easy to find, manage and understand by parents in their child's learning process.

All children who are born into the world have been perfected with various abilities, one of which is a creative ability or the ability to create. It's just that, these various kinds of abilities will not develop properly without a supportive environment and the help of the individuals around them. For this reason, it requires the development of creativity that can provide the best service for all aspects of early childhood development [2]. Education is in charge of developing the potential and creativity of students. Early childhood requires effective guidance in developing their abilities and potential optimally so that later they can be useful for themselves, families, and communities. Early childhood is in a sensitive period that is ready to absorb stimuli from the environment, so it is very important to develop all the potential of the child [3]. Education at an early age is education that is fundamental which has the aim of creating a better and more self-respecting human being. The main purpose of education is basically to stimulate the abilities of children from childhood and to prepare for life and be able to fit in with the environment [4].

WHO (World Health Organization) states that 
covid- 19 is a "global pandemic" so that people must obey each other to maintain health protocols during this pandemic to minimize the spread of the covid-19 virus and maintain body immunity [5]. After the "pandemic" was declared a global health emergency, all daily activities were hampered by the existence of mass restrictions from the government to prevent the spread of the covid-

19 virus [6]. Early childhood is individuals who are susceptible to exposure to the covid-19 virus. This has the effect of getting early childhood into the habit of being at home 24 hours a day. This can make early childhood quite familiar with gadgets so that the negative factors of gadget addiction itself can make early childhood creativity decrease or even sink, therefore the creation of early childhood during the Covid-19 pandemic needs to be researched.

\section{METHODS}

This study focuses on creativity in children. Research on creativity in early childhood is a research method using literature. Library research is one type of qualitative research that uses library sources to obtain research data. Strictly speaking, library research limits its activities only to library collection materials without requiring field research [7]. The object of this research is the theory of creativity in children, where the data taken comes from observations and extracting documents, such as using books, articles, historical stories as the data source of this research.

This research focuses on the study of creativity in early childhood in education, there is this research in data using analysis content analysis. The data obtained from library research are analyzed to obtain a conclusion that is valid and relevant to the research undertaken. Content analysis is a method used in getting conclusions from research using a method through manner characteristics message which is carried out in an actual and systematic [8].

\section{DISCUSSION}

Drevdahl argues that creativity is a person's ability to create something new in the form of designs, objects, or ideas that have never existed before [9]. Bloomberg [10] defines creativity as the total skill in the divergent thinking category. These categories have been defined as fluency, flexibility, originality, and elaboration ". Fluency is the ability for the produce and quantity of ideas on the topic. Flexibility is a change in perspective to a problem. Originality is generating unique ideas. Elaboration detailing which ideas are added. Penguin Dictionary Of Psychology [11] states that creative understanding is a thought process that can solve new or unique problems, ideas, designs, art, theories, or objects. Meanwhile, according to Coleman \& Hammen, there are three creative indicators, namely: the ability to think, an open attitude, have high imagination, selfconfidence, and have freedom of expression [11].

The definition of creativity is very diverse when viewed from various points of view of experts, where they define creativity differently, from various literature about the definition of creativity states that nothing is relevant in showing the agreement where creativity lies, whether in one's process or product. [12]. This shows that creativity varies considerably from one change to the next. This creativity can be a product, idea, or solution from someone who has high creativity with creative thinking personality traits so that creativity can be perceived in different ways as mental ability, process, and human behavior.

In other studies, it is stated that creativity is a thinking skill that is very important in creating innovations in the world of education that are new, meaningful, and also valuable [13]. Therefore, to develop early childhood creativity, innovation is also needed in planning learning, so that it can stimulate the creative abilities of early childhood during optimally the Covid-19 pandemic. Because in the present, individuals are required to have 21st-century skills which include: creativity, critical thinking skills, communication, and collaboration [14].

Creativity is usually thought to include two basic components: originality and usefulness, both of which play an indispensable role in solving practical problems in the real world. Originality requires a creative product that must be new, unique, and unconventional. Usability, on the other hand, requires creative ideas that must be applied to real objects for practical implementation. Apart from these factors, elements such as fantasy, imagination, curiosity, and originality are also needed for a child's creativity.

The characteristics of creative children are those who can think creatively and affective Creative thinking such as (1) fluency in thinking, (2) flexibility, (3) detailing, (4) original thinking, and (5) skills in evaluating. Meanwhile, affective (non-aptitude) has characteristics, such as (1) having great curiosity, (2) being imaginative, (3) liking challenges, (4) having the courage to take risks, and (5) being respectful [11]. Other experts argue that creative children have characteristics, namely (1) able to convey their opinions,

(2) independent in solving problems, (3) able to work,

(4) dare to try, and (5) able to communicate what they feel on an object [3]. 
There are two categories of creativity in innovation design: 1) creativity out-of-the-box, and 2) creativity in the form of a product resulting from a breakthrough. What is meant by creativity out-of-thebox is a type of creativity that generates ideas that originate from a belief in common sense / conventional / presumption. 15]. Therefore, in developing children's creativity, the $4 \mathrm{P}$ approach can be used, namely: (1) Personal; (2) Pusher; (3) Process, and (4) Product [16]. It is hoped that the child's uniqueness will emerge new, innovative ideas or products because good educators can appreciate the child's uniqueness. The encouragement of the surrounding environment in the form of support, appreciation, appreciation, incentives, and praise is needed by a child in realizing his creativity.

Process aspects, children need to be allowed to busy themselves to be creative, where the role of the teacher is only as a motivator/stimulus to children so they want to involve themselves in these creative activities. The product aspect is a condition in which a child can create a creative product that is useful/meaningful, in which the role of the teacher and the environment is only the driving force.

According to David Chapman [17] the role of kindergarten educators in designing children's games should have abilities, such as mastering the use of games, understanding creativity, acting as facilitators, being able to design challenging learning according to developmental tasks through fun games. Parents' behaviors that arouse children's creativity include, motivating children to express opinions and respect their opinions, freeing children to imagine, freeing children to make decisions, motivating children to ask questions, supporting what children do, facilitating children's activities, providing rewards, training children's independence, enjoying moments with children and collaborate well [18].

The first and foremost environment in the process of children's growth and development, is the family, especially parents need to pay attention to activities, behaviors, and patterns of care for children if they want to develop children's creativity. The development of children's creativity in the family is very important because it will help the development of children, both in the aspects of developing thinking, art, language, physical motor skills, and children's religious moral values [11]. Other studies show that the role of teachers can shape creativity. Creativity can be enhanced through social modeling, reinforcement, and classroom environments [19]. The position of the teacher is very important in developing creativity. In practice, social modeling, reinforcement, and classroom ecology is a design that requires a mentor. Thus, in implementing the social modification that treatments that focus on the development of creativity performed by a role model and guidance [19].

Imagination will affect children's creativity and artistic value in children [20]. One of the activities that can hone children's creativity with imagination is playing. There are three types of games that can hone early childhood creativity, namely creative play, active play, and play passively. Creative play provides opportunities for children to explore, work, express their feelings, which can cause fun, inspire children's creativity to work according to their fantasies. The goal is to optimize children's potential. Creative play classifications such as (1) creating objects; (2) connecting the story; (3) pretend to play or drama; (4) creative movement; and (5) creative questions.

Active play is an activity that is directly carried out by children so that it provides pleasure and satisfaction, such as playing spontaneously and freely, playing drama, playing constructively, collecting things, playing games and sports [21]. Passive play is a game that does not include children, only watching or listening, for example, such as reading, reading comics, watching movies, listening to music or radio. The function of playing includes training to think, improving sensory abilities, calming, stimulating creativity, training intellect, getting new things, and practicing caring [22].

Developing creativity in early childhood can use traditional games. Traditional games can develop children's creativity because they can invite children to imagine, for example by playing their role as mothers who have children using dolls. There is also a ship- callused game which this game can develop children's creativity and art because it takes the child's imagination to develop skills. Imagination will affect children's creativity and the value of art in children [20]

In increasing creativity in early childhood, traditional games are important, because children's world is a world of play. Increased creativity in early childhood where educators or teachers have their path to increase creativity children through traditional games. Traditional games can make children creative when playing. If children can express themselves and create forms in games, they are said to be creative [23]. In the early childhood literature, although the core principles of creativity (i.e., originality and value) also apply, children's creative novelty may be of more use exclusively to their social context than in society at large. Amabile argues that creative output is original when compared to the existing framework of 
children's cognition and behavior, and becomes valuable if it is meaningful to children [24].

During the Covid-19 pandemic, several Kindergarten schools facilitated children's learning by sending activities that children had to do through their parents. Parents or adults facilitate children's activities at home and record activities that children do during play. The video is then sent to the teacher for evaluation and analysis to determine the child's development. In this case, communication positive between parents and teachers must be built properly to ensure the effectiveness of children's learning and can grow and develop optimally [25]. At certain times the teacher and parents communicate to discuss the obstacles faced so that they can be solved together, the teacher provides education and guidance to parents on how to assist children and explore children's creativity in the right way. To make it easier for parents, learning activities are carried out using tools and materials available at home, simple media/materials, easily accessible to children and parents around their environment without having to buy, and ensure safety for the child's own safety, but can foster activities creative, such as playing science, playing languages, playing math, playing art, and playing music and motion.

\section{CONCLUSION}

Creativity can be defined as the human ability to create something according to his thoughts and feelings and is influenced by the environmental surroundings, especially the family environment. Therefore, close cooperation between parents and teachers is needed in learning from home for early childhood. Learning during the Covid-19 pandemic is carried out online, so that early childhood development and creativity can continue to be developed

\section{ACKNOWLEDGMENTS}

We would like to express our gratitude to the leaders of the University of Lambung Mangkurat who have provided the opportunity administratively and teachers and parents of students who have provided sources of information related to this research.

\section{REFERENCES}

[1] Kementerian Pendidikan Dan Kebudayaan Republik Indonesia. (2020). Surat Keputusan Menteri Pendidikan Dan Kebudayaan Nomor 719/P/2020 Tentang Pedoman Pelaksanaan Kurikulum Pada Satuan Pendidikan Dalam Kondisi Khusus. Jakarta: Kementerian Pendidikan dan Kebudayaan RI.
[2] Mulyasa. (2016). Manajemen Paud. Bandung: PT. Remaja Rosdakarya.

[3] Pekerti, W., \& Dkk. (2017). Metode Pengembangan Seni. Tangerang Selatan: Universitas Terbuka

[4] Susilo, S. (2016). Pedoman Akreditasi Paud. Jakarta: Bee Media Works Pustaka

[5] Handayani, R. T., Arradini, D., Darmayanti, A. T., Widiyanto, A., \& Tri, J. A. (2020). Pandemi Covid-19, Respon Imun Tubuh, Dan Herd Immunity. Jurnal Ilmiah Permas: Jurnal Ilmiah Stikes Kendal, 10 (3), 373-380.

[6] Putri, R. N. (2020). Indonesia Dalam Menghadapi Pandemi Covid-19. Jurnal Ilmiah Universitas Batanghari Jambi, 20 (2), 705-709.

[7] Hermawan, I. (2019). Metodologi Penelitian Pendidikan Kuantitatif, Kualitatif, Dan Mixed Methode. Kuningan: Hidayatul Quran Kuningan.

[8] Moleong, L. J. (2015). Metode Penelitian Kualitatif. Bandung: Pt. Remaja Rosdakarya.

[9] Musfiroh, T., \& Tatminingsih, S. (2016). Bermain Dan Permainan Anak. Tangerang Selatan: Universitas Terbuka.

[10] Dere, Z. (2019). Investigating The Creativity Of Children In Early Childhood Education Institutions. Universal Journal Of Educational Research, 7(3): 652-658.

[11] Handayani, P. H., Gandamana, A., \& Farihah. (2017). Pengembangan Kreativitas Anak Usia Dini Dalam Keluarga. Jurnal Keluarga Sehat Sejahtera, 15 (2), 46-56.

[12] Al-Ababneh, M. M. (2020). The Concept Of Creativity: Definitoins and Theories. Internasional Juornal of Tourism \& Hotel Management, 245- 249.

[13] Seechaliao, T. (2017). Instructional Strategies To Support Creativity And Inovation In Education. Journal Of Education Dan Learning, 6 (4), 201- 208

[14] Tsaniyah, A. B., \& Poedjiastoeti, S. (2017). Moge Learning Model To Improve Creative Thinking Skills. International Journal of Education And Research, 17 (2), 160-166.

[15] Taura, T., \& Nagai, Y. (2017). Creativity In Innovation Design: The Role Of Intuition, Synthesis, And Hypothesis. International Journal Of Design Creativity And Innovation, 5 (3), 131- 148.

[16] Sit, M, Dkk. (2016). Pengembangan Kreativitas Anak Usia Dini. Medan: Perdana Publishing.

[17] Anhusandar, L. O. (2016). Kreativitas Pendidik di Lembaga Paud. Jurnal Al-Ta'dib, 9 (1), 7693. 
[18] Rachman, S. A. (2020). Penguatan Peran Orang Tua Dalam Mendampingi Pendidikan Anak Di Masa Pandemi Covid-19. Jurnal Golden Age, Universitas Hamzanwadi, 4 (2), 322-332.

[19] Kaycheng, S. (2017). Fostering Student Creativy Through Teacher Behaviors. Thinking Skills And Creativity. Sciencedirect Journals, 23, 58-66.

[20] Hasanah, N. I., \& Pratiwi, H. (2016). Pengembangan Anak Melalui Permainan Tradisional. Yogyakarta: Aswaja Pressindo

[21] Hurlock, E.B. (2002). Psikologi Perkembangan. Terj. Istiwidiyanti Dan Soedjarwo. Jakarta: Erlangga.

[22] Putro, K. Z. (2016). Mengembangkan Kreativitas Anak Melalui Bermain. Jurnal Aplikasi Ilmu-Ilmu Agama, 16 (1), 21-26.

[23] Nurlailah, \& Mutmainna. (2018). Penggunaan Permainan Tradisional Dalam Meningkatkan Kreatifitas Anak Usia Dini. Jurnal Al-Athfal, 13 (2), 27-35.

[24] Frith, E., Loprinzi, P., \& Miller, S. E. (2019). Role Of Embodied Movement In Assessing Creative Behaviorin Early Childhood: A Focused Review. Sage Journals, 126 (6), 10581083.

[25] Hasbi, M., Murtiningsih, Rosita, W., Tamara, H., \& Rahayu, I. (2020). Membangun Komunikasi Positif Antara Guru Dengan Orang Tua Murid (Selama Kebijakan Belajar Dari Rumah). Jakarta: Kementerian Pendidikan Dan Kebudayaan. 